\title{
A Comparison of Chemical Composition and Yield of Essential Oils from Shoot System Parts of Ocimum sanctum Found in Semi-Arid Region of Uttar Pradesh
}

\section{Tanuja Saroj ${ }^{1 *}$ and Alok Krishna ${ }^{1}$}

${ }^{1}$ Technology and Business Development Division, Council of Scientific and Industrial Research (CSIR)-Central Institute of Medicinal and Aromatic Plants (CIMAP), Lucknow, India

\begin{abstract}
Ocimum sanctum (O. sanctum) Linn. synonym Ocimum tenuiflorum is an aromatic and medicinal plant used in whole world. The hydrodistillation essential oils (EO) of $O$. sanctum four varieties viz. CIM-Ayu, CIM-Angna, local Rama Tulsi and local Syama Tulsi was investigated using GC and GC/MS techniques on DB-( $5 \%$ diphenyl-95\% dimethyl polysiloxane) capillary columns. EO extracted from the leaves, stem and flower parts of $O$. sanctum plant. The O. sanctum plant found in semi-arid region of Uttar Pradesh (U.P.) chemical composition and EO yield no one research paper published yet. So, this investigation was carried out to determine the chemical composition and yield of EO of $O$. sanctum plant found in semi-arid region of U.P. The identified main constituents of EO were almost same in all varieties of $O$. sanctum plant dominated by eugenol, $\beta$-selinen, 4,10 (14)-muuroladien-8. $\beta$-ol, (R)-cembrenene, trans-Caryophyllene, camphene and sabinene. The other components were 1 , 8 -Anhydro-cis-. $\alpha$-copaene-8-ol, $\beta$-elemene, $(+)-\beta$-costal and $\alpha$-copaene. These compounds have biological importance showing through various citiation literatures. In the fresh herb of shoot system parts (leaves, stems and flowers) of $O$. sanctum, EO highest yield in CIM-Ayu (0.5\%) as compared to CIM-Angna (0.4\%), local Syama Tulsi $(0.3 \%)$ and local Rama Tulsi $(0.2 \%)$.
\end{abstract}

Keywords: Ocimum sanctum; EO; U.P; Semi-arid region; Eugenol; Germacrene-D

\section{Introduction}

Ocimum sanctum (O. sanctum) is a medicinal [1] plant comprising of different species. It is found throughout the world from an ancient period and commonly cultivated in gardens and holy places in India. O. sanctum Linn. belonging to the family Lamiaceae commonly known as Tulsi in Hindi and holy Basil in English. O. sanctum is an aromatic herb, much branched soft hairy and $30 \mathrm{~cm}-75 \mathrm{~cm}$ high. Leaves ellipticoblong, acute or obtuse, entire or serrate, pubescent on both sides, minutely gland-dotted; flowers are purplish or crimson, found in racemes, close whorled, broadly ellipsoid, slightly compressed, nearly smooth, pale brown or reddish, with the small black markings. $O$. sanctum has a very wide range of distribution, it covers mostly the entire Indian sub-continent, its presence has been reported in high altitude of Himalayan regions up to the $1800 \mathrm{~m}$ of height and reported in the far regions of Andaman and Nicobar Islands. O. sanctum grown under contract organic farming in the semi-arid region of central India in the district Hamirpur of Uttar Pradesh (U.P.). Hamirpur geographical status is $25^{\circ},-95^{\circ} \mathrm{N}$ to $80^{\circ}-15^{\circ} \mathrm{E}$ and an average elevation of $80 \mathrm{~m}$ [2]. It lies between latitude $25^{\circ} \mathrm{N}$ and $6^{\circ} 7^{\prime} \mathrm{N}$ and longitude $79^{\circ} 17^{\prime} \mathrm{E}$ and $80^{\circ} 21^{\prime} \mathrm{E}$ temperature varies between $3^{\circ} \mathrm{C}$ to $46^{\circ} \mathrm{C}$ and annual rainfall is $750 \mathrm{~mm}$ to $1000 \mathrm{~mm}$ [2]. The soils found Kabar (Black cotton soil) with $\mathrm{pH}$ ranges between 7 to 8.5 and rich in organic fertilizer [2]. The organic matters considered as one of the important factors of soil fertility due to their beneficial effects on the physical, chemical and biological productivity of the soil. O. sanctum plant used in the treatment of bronchitis, bronchial asthma, malaria, diarrhea, dysentery, skin diseases, arthritis, painful eye diseases, chronic fever, insect bite etc. The extract of the $O$. sanctum shows radioprotective activity $[3,4]$. Due to genetic and environmental factors composition of essential oils (EO) varies which influence the genetic expression of plant [5]. Essential oils of $O$. sanctum plant have a diverse group of natural products that are important sources of aromatic and flavoring chemicals in food, pharmaceutical and industrial products [6]. But there is no published research report found in the literature about the EO major constituents in different varieties of $O$. sanctum grown in semi-arid region of U.P. So, an attempt has been made to investigate the major components of EO found in O. sanctum grown in semi-arid region of U.P. In this paper, we compare the chemical composition and yield of EO from shoot system parts of $O$. sanctum plant found in semiarid region of U.P. This paper shows essential oils high yield variety of O. sanctum.

\section{Materials and Methods}

\section{Collection of plant material}

The plant material collected during October 2014 from the local farmers of semi-arid region Hamirpur, a district of Uttar Pradesh. Since last 6-7 yrs, local farmers are organic growers of O. sanctum crop under contract farming with Organic India.

\section{Isolation of essential oil}

The fresh herb (leaves, stem and flowers) used for extraction after removal of all dust and foreign particles of $O$. sanctum plant. In each sample $500 \mathrm{~g}$ leaves were used. The sample was hydro-distilled in Clevenger apparatus for $6 \mathrm{~h}$. The yield of EO was obtained $0.8 \% \mathrm{v} / \mathrm{w}$.

*Corresponding author: Tanuja Saroj, Technology and Business Development Division, Council of Scientific and Industrial Research (CSIR)-Central Institute of Medicinal and Aromatic Plants (CIMAP), P.O. CIMAP, Lucknow-226015, India, Tel: 0522271 9083; E-mail: tanujasaroj4@gmail.com

Received November 02, 2017; Accepted November 28, 2017; Published December 05, 2017

Citation: Saroj T, Krishna A (2017) A Comparison of Chemical Composition and Yield of Essential Oils from Shoot System Parts of Ocimum sanctum Found in Semi-Arid Region of Uttar Pradesh. Agrotechnology 6: 172. doi: 10.4172/2168-9881.1000172

Copyright: @ 2017 Saroj T, et al. This is an open-access article distributed under the terms of the Creative Commons Attribution License, which permits unrestricted use, distribution, and reproduction in any medium, provided the original author and source are credited. 
In the graduated tube yellow colored EO was collected. The collected EO was dried over an anhydrous sodium sulphate and stored in the dark at $4^{\circ} \mathrm{C}$.

\section{GC analysis}

GC analysis was carried out on a Varian 3800 Gas Chromatograph fitted with a silicone DB-5 capillary column $(30 \mathrm{~m} \times 0.25 \mathrm{~mm})$, film thickness $0.25 \mu \mathrm{m}$, nitrogen was used as a carrier gas, flow rate $1.0 \mathrm{~mL} /$ min., a split ratio of $1: 40$, temperature programmed $180^{\circ} \mathrm{C}-250^{\circ} \mathrm{C}$ at $4^{\circ} \mathrm{C} / \mathrm{min}$. Injector temperature and detector temperature were $250^{\circ} \mathrm{C}$ and $300^{\circ} \mathrm{C}$ respectively. Detector used was Flame ionization detector (FID). Injector volume for all samples was $0.1 \mu \mathrm{l}$. Total GC running time was $61 \mathrm{~min}$.

\section{GC-MS analysis}

GC-MS analysis done on a Schimadzu QP-2000 instrument using ULBON HR-1 fused silica capillary column $(50 \mathrm{~m} \times 0.25 \mathrm{~mm}$ $\times 0.25 \mu \mathrm{m}$ film thickness) at EI mode $70 \mathrm{eV}$ and $250^{\circ} \mathrm{C}$ ion source temperature. Carrier gas was helium at a flow rate of $2 \mathrm{~mL} / \mathrm{min}$. The initial temperature was $100^{\circ} \mathrm{C}$ for $6 \mathrm{~min}$. and then heated at a rate of $10^{\circ} \mathrm{C} / \mathrm{min}$ to $250^{\circ} \mathrm{C}$

\section{Results and Discussion}

\section{Identification of components}

The EO components identification was done by comparison of retention indices of GC chromatograph of the peaks with those of compounds reported in literature [4] and computer matching of mass spectra with standards Wiley L-built libraries and Tutorial data of GC MS systems.

\section{Discussion}

By GC and GC-MS, the constituents of EO were identified. Retention time (RT) and percentage composition of each constituent are listed in Table 1. The hydro-distillation of the leaves, stem and flower parts of O. sanctum at full flowering stage in all four varieties total eleven components of essential oil were identified. In four varieties of $O$. sanctum, highest amount of Eugenol found in CIMAngna (78.3\%), local Syama Tulsi (62.7\%), CIM-Ayu (42.9\%) and local Rama Tulsi (23.4\%) while $\beta$-Selinen is high amount in CIM-Ayu (29.1\%), local Rama Tulsi (26.9\%) and local Syama Tulsi (11.3\%). In CIM-Angna, $\beta$-Selinen is in low amount $(7.4 \%)$. The compound 4,10(14)-Muuroladien-8. $\beta$-ol is higher amount in local Rama Tulsi
(28.7\%) as compaired to local Syama Tulsi (18.6\%), CIM-Ayu (17.8\%) and CIM-Angna (9\%). The percentage of compound 1, 8-Anhydrocis-.a-Copaene-8-ol in local Rama Tulsi is (1.6\%), CIM-Angna (1.5\%), CIM-Ayu (1.3\%) and local Syama Tulsi (1\%). (R)-Cembrenene compound from higher amount to lower found in CIM-Angna (9.3\%), local Rama Tulsi (3.3\%), CIM-Ayu (2.5\%) and local Syama Tulsi $(0.1 \%)$ respectively. The oil Component trans-Caryophyllene found in higher amount in only two varieties viz. CIM-Ayu (2.6\%) and CIMAngna (1.5\%) while in local Rama Tulsi and local Syama Tulsi shows in very low amount $0.8 \%$. The component $\beta$-Elemene found higher amount in local Syama Tulsi (1.6\%), CIM-Ayu (1.4\%) and CIM-Angna (1\%) while in local Rama Tulsi have trace amount of this component i.e., $0.7 \%$. Other compound (+)- $\beta$-Costal component is in higher amount in local Rama Tulsi (1.4\%), CIM-Ayu (1\%), CIM-Angna (1\%) and trace amount in local Syama Tulsi. Camphene compound is detected more in CIM-Angna (2.2\%), local Rama Tulsi (1.8\%), CIMAyu (1.7\%) and low in local Syama Tulsi (0.1\%). CIM-Angna (6.7\%) and CIM-Ayu (6.3\%) having higher amount of Sabinene compound in comparison to local Rama Tulsi (0.4\%) and local Syama Tulsi $(0.2 \%)$. the $\alpha$-Copaene component is found more amount in local Rama Tulsi (1.6\%), CIM-Ayu (1.3\%), CIM-Angna (1.2\%) and less in local Syama Tulsi $(0.5 \%)$. In trace amount many other constituents are also detected. Eugenol, $\beta$-Selinen, 4,10(14)-Muuroladien-8. $\beta$-ol, (R)-Cembrenene, trans-Caryophyllene, Camphene and Sabinene are major components identified in all four varieties of O. sanctum EO. Eugenol comprise the major fraction of the oil followed BY $\beta$-Selinen and 4,10(14)-Muuroladien-8. $\beta$-01. Whole plant of Ocimum sanctum contains eugenol which is an antibacterial component used for pharmacological work [7] and as a phenylpropanoid compound. This is also used in perfumes, flavorings as well as antiseptic and anesthetic [8]. The essential oil yielded as $0.5 \%$ in CIM-Ayu, $0.4 \%$ in CIM-Angna, $0.3 \%$ in local Rama Tulsi and $0.2 \%$ in local Syama Tulsi. This shows CIM-Ayu performs better in organic field of semi-arid region of Uttar Pradesh. Many results reported the chemical composition and yield of EO of O. sanctum [9-11] but O. sanctum plant grown under organic field of semi-arid region of Uttar Pradesh are being reported for the first time by this research paper.

\section{Conclusion}

The medicinal value of $O$. sanctum plant grown in organic condition proved through many published reports. The presence of EO constituents justifies the uses of the Tulsi herb in various forms like as spices in food industry, in aromatherapy or as a cosmetic additive

\begin{tabular}{|c|c|c|c|c|c|c|}
\hline \multirow{3}{*}{ S. No. } & \multirow{3}{*}{ Identified components } & \multirow{3}{*}{${ }^{\mathrm{a}} \mathbf{R T}$} & \multicolumn{4}{|c|}{ Peak area $\%$} \\
\hline & & & \multicolumn{4}{|c|}{ Varieties of Ocimum sanctum } \\
\hline & & & CIM-Ayu & CIM-Angna & Local Rama Tulsi & Local Syama Tulsi \\
\hline 1 & Eugenol & 28.57 & 42.95 & 78.34 & 23.45 & 62.75 \\
\hline 2 & $\beta$-Selinen & 30.11 & 29.12 & 7.4 & 26.97 & 11.3 \\
\hline 3 & $4,10(14)$ - Muuroladien-8. $\beta$-ol & 31.46 & 17.77 & 9.06 & 28.73 & 18.58 \\
\hline 4 & 1, 8-Anhydro-cis- $\alpha$-Copaene-8-ol & 32.81 & 1.27 & 1.5 & 1.63 & 1.05 \\
\hline 5 & (R)-Cembrenene & 33.88 & 2.53 & 9.27 & 3.27 & 0.14 \\
\hline 6 & trans-Caryophyllene & 34.44 & 2.61 & 1.52 & 0.85 & 0.78 \\
\hline 7 & $\beta$-Elemene & 35.41 & 1.42 & 1.02 & 0.71 & 1.57 \\
\hline 8 & $(+)-\beta-$ Costal & 36.38 & 1.06 & 1.04 & 1.37 & 0.07 \\
\hline 9 & Camphene & 37.9 & 1.66 & 2.18 & 1.83 & 0.13 \\
\hline 10 & Sabinene & 38.22 & 6.3 & 6.66 & 0.38 & 0.22 \\
\hline 11 & a-Copaene & 40.5 & 1.34 & 1.24 & 1.65 & 0.51 \\
\hline
\end{tabular}

Table 1: Essential oils constituents found from shoot system parts of $O$. sanctum $L$. 
Citation: Saroj T, Krishna A (2017) A Comparison of Chemical Composition and Yield of Essential Oils from Shoot System Parts of Ocimum sanctum Found in Semi-Arid Region of Uttar Pradesh. Agrotechnology 6: 172. doi: 10.4172/2168-9881.1000172

Page 3 of 3

and in cure of many diseases. The farmers can make good money by selling essential oils to various kinds of industries. Thus, $O$. sanctum is emerging as an economical crop for the farmers and traditional practitioners.

\section{Acknowledgment}

We are grateful to the Director, Council of Scientific and Industrial Research (CSIR)-Central Institute of Medicinal and Aromatic Plants (CIMAP), Lucknow, India for providing necessary facilities to undertake this work and thanks to organic farmer of Hamirpur district of Uttar Pradesh for their valuable contribution. We are also special thankful to University Grant Commission (UGC), New Delhi who giving financial support to the author Tanuja Saroj in the form of UGC-Junior Research fellowship (JRF) (Reference Number F.2-13/2006 (SA-I)).

\section{References}

1. Bariyah SK (2013) An extensive survey of the phytochemistry and therapeutic potency of Ocimum sanctum (Queen of Herbs). Pak J Chem 3: 8-18.

2. Yadav HK, Singh S, Kumar V, Yadav RP, Alok K (2012) Productivity evaluation of organically grown Ocimum sanctum and Ocimum gratissimum leaves under rainfed condition of Central India. International Journal of Current Research 4: $90-92$.

3. Pingalea SS, Narayan P, Firke B, Markandeya AG (2012) Therapeutic activities of Ocimum tenuiflorum accounted in last decade: A review. Journal of Pharmacy Research 5: 2215-2220.

4. Dohare SL, Ahmad MI, Shuaib M, Naquvi KJ (2012) Chemical composition of volatile oil of Ocimum sanctum Linn. International Journal of Biomedical and Advance Research 3: 129-131.

5. Bernath J (1986) Production ecology of secondary plant products. In: LE Craker, JE Simon (eds) Herbs, spices and medicinal plants: Recent advances in botany, horticulture and pharmacology. Vol. 1. Oryx Press, Phoenix, Ariz 185-234.

6. Denys JC, James ES (1990) Comparison of extraction methods for the rapid determination of essential oil content and composition of Basil. J Amer Soc Hort Sci 115: 458-462.

7. Devendran G, Balasubramanian U (2011) Qualitative phytochemical screening and GC-MS analysis of Ocimum sanctum L. leaves. Asian Journal of Plant Science and Research 1: 44-48.

8. Saharkhiz MJ, Kamyab AA, Kazerani NK, Zomorodian K, Pakshir K, et al. (2015) Chemical composition and antimicrobial activities of Ocimum sanctum L. Essential oils at different harvest stages. Jundishapur J Microbiol 8: e13720.

9. Silva MR, Oliveira JG Jr, Fernandes OF, Passos XS, Costa CR, et al. (2005) Antifungal activity of Ocimum gratissimum towards dermatophytes. Mycoses 48: $172-175$.

10. Trevisan MT, Owen RW (2006) Characterization of the volatile pattern and antioxidant capacity of essential oils from different species of the genus Ocimum. J Agic Food Chem 54: 4378-4382.

11. Chalchat JC, Ozcan MM (2008) Comparative essential oil composition of flowers, leaves and stems of basil (Ocimum basilicum L.) used as herb. Food Chemistry 110: 501-503. 